\title{
Factors Influencing Credit Management as a Strategy on the Performance of SACCOS in Nairobi City County: A Case of Ukulima SACCO
}

\author{
Jane Wambui Gichuki ${ }^{1}$, Dr. Asumptah W. Kagiri ${ }^{2}$ \\ ${ }^{1}$ MBA- Jomo Kenyatta University of Agriculture and Technology \\ ${ }^{2}$ Supervisor, Lecturer, Jomo Kenyatta University of Agriculture and Technology
}

\begin{abstract}
This study examined the factors that influence credit management as a strategy in the performance of SACCOs in Nairobi City County. The study was limited to Ukulima SACCO. The study was guided by solving of the specific objectives which are Common bond, Collateral requirement, Credit risk, and Loan repayment ability. The study adopted a descriptive survey design utilizing both primary and secondary data. Structured and unstructured questionnaires were used to collect primary data which were administered through 'drop and pick later' method while secondary data was collected through document review. Data analysis was carried out using qualitative and quantitative techniques with the aid of SPSS while the main method of data presentation was frequency distribution, tables, pie charts and bar graphs. The study found out that restriction of loan guarantee creates friction among members. The analysis of the data shows that most members suggest that SACCOs to open the loan guarantee and include other collaterals to secure the loans. The study recommends education to SACCO members to immediately address the credit management issues by encouraging members to save regularly, borrow wisely for productive purposes and repay their loans promptly. The study also recommends that credit policy should be reviewed by SACCOs from time to time to reflect the economic trends due to the changing world of business; hence efforts on credit management strategy will be enhanced.
\end{abstract}

Keywords: Common bond, Collateral requirement, Credit risk, and Loan repayment ability

\section{Introduction}

Co- operative societies have outlived their initial ideas of being welfare associations and have been transformed into big business enterprises especially in the developing nations. The core objective of SACCOs is to ensure members empowerment through mobilization of savings and disbursement of credit (Ofei, 2001). SACCOs in Kenya in their struggle to achieve this objective have been able to mobilize over Kshs.200 billion in savings (CBK, 2010).

Credit management is the main driver for economic growth and progress of SACCOs. SACCOs consider credit management as a major engine to enhance their performance and to strengthen their competitive position in the market. Many firms have paid most of their management attention to a greater focus on internal efficiencies of the development process, team structures, decision making and cross functional interaction (Eirma, 2004). However, as more and more companies bring credit management straight to the heart of their corporate strategies, developing credit management policies is no longer sufficient to gain and sustain competitive advantage. The management needs to strategize on how to implement these polices.

The problem of the study is to establish why SACCOs borrow funds from commercial banks for on-lend to its members. Alarcon (2008) indicated that the most important constraint for SACCOs is not to expand their outreach, but having limited sources of funds, but he did not seek to find out the strategies to bridge the said gap. Hence the need for establishing the factors that influence credit management as one of the strategies. KUSCCO (2006) in their results shows that some SACCOs are large enough to become banks. It is against this background that this study will be conducted to establish the factors that influence credit management as a strategy in the performance of SACCOs in Nairobi City County.

\section{Specific objectives}

1) To establish how the member common bond affect credit management on the overall performance of SACCOs.

2) To determine the effect of collateral requirements on credit management on the overall performance of SACCOs.

3) To establish the effect of credit risk on credit management on the overall performance of SACCOs.

4) To determine how the member loan repayment ability affects credit management on the overall performance of SACCOs.

\section{Literature Review}

\subsection{Theoretical Framework}

Research has been done on performance of loans in Financial institutions. A number of theories have been developed. Understanding of these theories will facilitate the managers to get a better insight in credit management.

\subsection{The Grameen Solidarity Group Theory}

Armendariz et al, (2005) elaborates the base of this model as group's peer pressure whereby loans are made to individuals in groups of four to seven. Group members collectively guarantee loan repayment, and access to subsequent loans is dependent on successful repayment by all group members on 


\section{International Journal of Science and Research (IJSR) \\ ISSN (Online): 2319-7064}

Index Copernicus Value (2013): 6.14 | Impact Factor (2014): 5.611

weekly basis. SACCOs can use this type of microfinance model which is effective in deterring defaults.

\subsection{Agency Theory}

Agency theory identifies the agency relationship where one party, the principal delegates work to another party, the agent " (Malin 2007).Agency theory extends the analysis of the firm to include separation of ownership and control, and managerial motivation. Managers being the agents of SACCOs, owners must be monitored and some checks and balances must be instituted to ensure that they do not abuse their power. They should follow direction and guidelines put in place. This ensures that managers work towards profit maximization which means high returns to shareholders. The SACCO under sound credit management have credit policy put in place and facilitates the lending services which results in more improving the well being, growth and development of its members.

\subsection{Political Theory}

In Nigeria, many SACCOs have been formed as a result of certain government officials being authorized to form them in the villages that they were born (Enete, 2008 as cited in Odera, 2012). The credit management of such political SACCOs can be manipulated such that the decisions made reflect the desires of the politicians and not of the interests of the shareholders thereby affecting the performance of the SACCO, leading to low returns to shareholders.

\subsection{Credit Risk Portfolio Theory}

Pandy (2005) illustrates as he points out that credit policy defines a firm's performance. Meaning that once a firm adopts an optimal credit policy, it will be able to maximize its investment revenue in debtors and this improves and promotes its financial standing and performance. This theory helps the SACCO management to see to it that as they execute the credit policy in service to their members thereby increasing their revenue hence improving the overall performance.

\subsection{Conceptual Framework}

The conceptual framework shows the relationship between the independent variables and the dependent variable. Independent variables are member common bond, collateral requirements, credit risk and ability to repay loan, the dependent variable which is the performance of the SACCOs.

\subsection{Research Gaps}

In as much as a lot of research has been done on non performance of loan, most of the local studies have leaned on various variables identified in various institutions. Brugger (2004) notes that SACCOs, like any other financial institution, must have a minimum amount of its own capital for reducing the risks of its lenders and depositors and that the costs of doing business are high relative to the value of loans and deposits involved. Most of the studies are done on other institutions other than SACCOs. Therefore, there exists a research gap on the factors that influence credit management as a strategy in the performance of SACCOs in Kenya.

\section{Methodology}

The study adopted a descriptive survey design. The target population was made of 486 members. 9 Board of Directors, 42 senior managers, 150 operation staff and 285 delegates.

The study adopted Simple random technique. According to Ngechu, (2004) simple random sampling technique produces estimates of overall population with greater precision and ensures that more representative sample is derived from a relatively homogenous population. According to Mugenda and Mugenda (2003), sampling is the process of selecting respondents from the target population in a statistical survey with varying population, its advantageous to sample each sub group independently, each element in the population is assigned to only one subgroup and no element should be excluded.

The sample size was arrived at using the following formula: $\mathrm{n}=\mathrm{NC}^{2}$

$\mathrm{C}^{2}+(\mathrm{N}-1) \mathrm{e}^{2}$

Where, $\mathrm{n}$, is the sample size,

$\mathrm{N}$, is the population size,

$\mathrm{C}$, is the coefficient of variation which is $\leq 30 \%$, and

$\mathrm{e}$, is the margin of error which is fixed between $2-5 \%$

The study sample was calculated at less than thirty percent coefficient of variation which was $15 \%$ and $2 \%$ margin of error. Thus the sample size was determined through the following calculations;

$\mathrm{n}=486(0.15)^{2}=50$

$0.1 \overline{5^{2}+(486-1)} 0.02^{2}$

The sample comprised 50 members of the SACCO.

\subsection{Data Analysis}

The data collected was sorted, coded and analyzed with the aid of Statistical Package for Social Sciences (SSPS V 20.0) using descriptive statistics. Data collected was analyzed using descriptive statistics and inferential statistics. Descriptive analysis using frequencies, percentage, mean and standard deviation was used to help to understand and interpret variables. Both descriptive and content analysis techniques were employed. Regression analysis was also used to establish the relationship between the independent variables and the dependent variable.

The following multiple regression analysis equation was used to determine the relationship between performance of the SACCOs and independent variables.

$\mathrm{Y}=\mathrm{a}+\mathrm{b} 1 \mathrm{x} 1+\mathrm{b} 2 \times 2+\mathrm{b} 3 \times 3+\mathrm{b} 4 \times 4+\mathrm{e}$

$\mathrm{Y}=$ Dependent variable - (Performance of the SACCOs)

$\mathrm{a}=$ constant

b1-4= Regression coefficients

$\mathrm{x} 1-4=$ Independent variables

$\mathrm{x} 1=$ loan repayment ability

$\mathrm{x} 2=$ credit risk

$\mathrm{x} 3=$ collateral requirements

\section{Volume 4 Issue 11, November 2015}




\section{International Journal of Science and Research (IJSR) \\ ISSN (Online): 2319-7064}

Index Copernicus Value (2013): 6.14 | Impact Factor (2014): 5.611

$\mathrm{x} 4=$ member common bond

\section{$\mathrm{e}=$ Error term}

The qualitative data was analyzed qualitatively through capturing the common answers based on their commonality through content analysis.

\subsection{Data Presentation}

The quantitative data was presented using statistical tools such as frequency tables, pie charts and bar graphs as was found appropriate, for easy understanding. The researcher then interpreted the research findings from the evidence presented by the data collected. Conclusions are based on the findings. According to Mugenda\&Mugenda (2003) recommendations must be consistent with purpose of the study and its objectives. Therefore, guided by the objectives of the study the researcher made recommendations.

\section{Results and Discussion}

The data collection instrument was a questionnaire which was sent to a sample of 50 respondents. However 49 respondents out of the 50 questionnaires which were distributed gave a response. This response rate was considered adequate for reporting as it exceeded the generally accepted threshold of 50\% (Mugenda \& Mugenda 2003).

\section{Respondents by Period in Membership}

According to the results $10.2 \%$ of the respondents had been in the SACCO for duration of less than 10 years, $32.7 \%$ had been in the SACCO for duration of 11-20 years and $34.7 \%$ had been in the SACCO for duration of 20- 30 years, and $22.4 \%$ had been in the SACCO for duration of over 30 years. This illustrates that majority of the SACCO members have been in membership for more than 20 years, which demonstrates member loyalty.

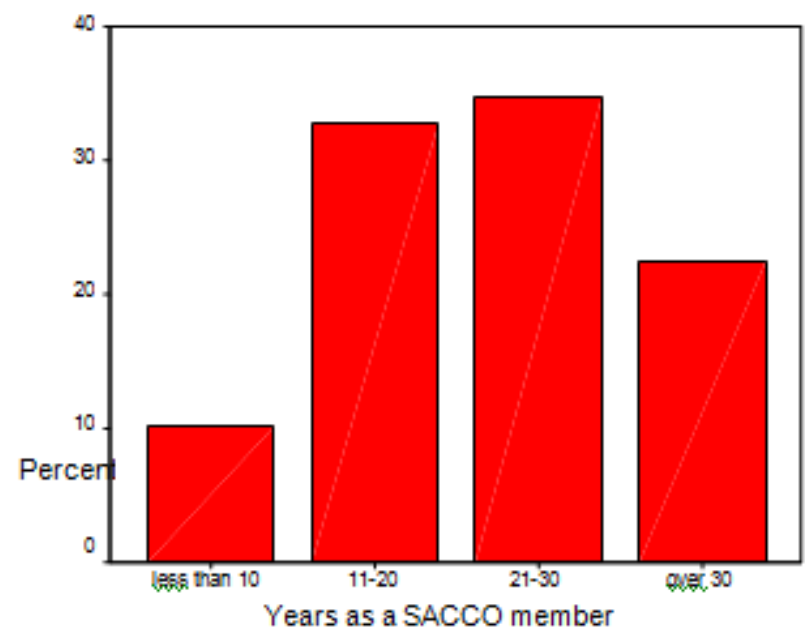

Figure 4: Years as a SACCO Member Common Bond

\section{Common Bond}

From the findings, $10.2 \%$ of the respondents indicated that members common bond affects performance of the SACCOs to a small extent, $14.3 \%$ of the respondents indicated that members common bond affect performance of the SACCOs to a moderate extent, $24.5 \%$ of the respondents indicated that members common bond affect performance of the SACCOs to big extent and $51 \%$ of the respondents indicated that members common bond affect performance of the SACCOs to a great extent. This demonstrates the initial government requirement on member relationship as per Planet Rating East Africa, SACCO growth Report, (2007). This further concurs with Wolf (1910) as cited by Uluma (2009) in his study on an assessment of the determinants of growth of SACCOs in Dagoretti district in Kenya, where he observed that interconnection of liability among members is created by the bond, which may either involve direct and unlimited financial liability, or direct responsibility for good management. Co-operatives common bond limit its scope and field from which membership is drawn.

\section{Collateral Requirement}

The study sought to find out the extent that collateral requirement affect performance of the SACCOs. From the findings, $8.2 \%$ of the respondents indicated that collateral requirement affects performance of the SACCOs to a small extent, $14.3 \%$ of the respondents indicated that collateral requirement affect performance of the SACCOs to a moderate extent, $34.7 \%$ of the respondents indicated that collateral requirement affect performance of the SACCOs to a big extent and $42.8 \%$ of the respondents indicated that collateral requirement affect performance of the SACCOs to a great extent. This is in line with the way SACCOs are changing their policies in order to attract clientele as advocated by Horne and Chisty (2011). This is also inconsistent with findings of Sandino et al (2012) in their study on effectiveness of credit management system on loan performance in MFIs in Kenya, whereby they found out that there is a significant relationship between collateral attached as security and loan performance, and they further recommended that MFIs must evaluate the collateral used as security when appraising clients because this can be used to service the loan in case of any default.

\section{Credit Risk}

From the findings, $38.8 \%$ of the respondents indicated that credit risk affects performance of the SACCOs to a lesser extent, $42.8 \%$ of the respondents indicated that credit risk affect performance of the SACCOs to a small extent, 8.2\% of the respondents indicated that credit risk affect performance of the SACCOs to moderate extent and $10.2 \%$ of the respondents indicated that credit risk affect performance of the SACCOs to a great extent. This concurs to the recommendation by Fernard et.al (2000) adjusted rate of return by maintaining credit risk exposure within acceptable parameters.

\section{Loan Repayment Ability}

As per the results, $10.2 \%$ of the respondents indicated that loan repayment ability affect performance of the SACCOs to a small extent, $4.1 \%$ of the respondents indicated that loan repayment ability affect performance of the SACCOs to a moderate extent, $26.5 \%$ of the respondents indicated that loan repayment ability affect performance of the SACCOs to

\section{Volume 4 Issue 11, November 2015}




\section{International Journal of Science and Research (IJSR) \\ ISSN (Online): 2319-7064}

Index Copernicus Value (2013): 6.14 | Impact Factor (2014): 5.611

a big extent and $59.2 \%$ of the respondents indicated loan repayment ability affect performance of the SACCOs to a great extent. This is in agreement with Njeru (2015) in his study on effect of loan repayment on financial performance of deposit taking SACCOs in Mt. Kenya region. According to his findings, there is a strong relationship between loan repayment and financial performance. He further concluded that members have an obligation to ensure that SACCOs have adequate cash to meet new loan applications to their fellow members.

\section{Regression Analysis}

The researcher conducted a linear regression analysis so as to test relationship among variables (independent) on performance of the SACCOs. The researcher applied R to code, enter and compute the measurements of the linear regressions for the study. Coefficient of determination explains the extent to which changes in the dependent variable can be explained by the change in the independent variables or the percentage of variation in the dependent variable (performance of SACCOs) that is explained by all the four independent variables (common bond, collateral requirement, credit risk and loan repayment ability). The four independent variables that were studied, explain only $90.3 \%$ of the performance of SACCOs as represented by the adjusted $\mathrm{R}^{2}$. This therefore means that other factors not studied in this research contribute $9.7 \%$ of the performance of SACCOs. Therefore, further research should be conducted to investigate the other factors $(9.7 \%)$ that affect performance of SACCOs.

\section{Conclusions}

The researcher had different results from the instruments used for data analysis and interpretation and the conclusion arrived at was that several factors affect credit management in SACCOs. The management needs to spend most of its time on this strategy that acts as a reference for best practices for the identification and analysis of risks in lending propositions and for the monitoring and control of society's loans. Failure to display the attributes that measure credit management will reduce customer loyalty and more so can lead to SACCO insolvency.

\section{Recommendations}

It is recommended that there is need to immediately address the credit management issues by encouraging members to save regularly, borrow wisely for productive purposes and repay their loans promptly. Education to members is very crucial as it should be done on regular basis on SACCO operations, governance, and entrepreneurial skills, banking culture and loan management and obligation of the borrowers to repay the loan. Collateral requirement is of concern and SACCOs should review their appraisal terms and conditions to open the loan guarantee and include other types of collaterals like title deeds and logbooks.

The credit policy should be reviewed from time to time to reflect the economic trends due to the changing world of business. Delinquency management is of concern which will be reduced through open collateral requirements which will also advocate for opening of common bond.

\section{References}

[1] Central Bureau of Statistics (2006), Economic Survey. Ministry of Planning \&National Development, Government Printers.

[2] Chandler A. (1990).Strategy and Structure, Cambridge, MA: MIT Press, Commission on Public Policy and British Business, (1997).Determinants of competitive advantage. Cambridge, London and N.Y: Cambridge University Press

[3] Cooper, D.R \& Schindler, P.S (2003). Business Research Methods. New York: Mc

[4] Cooper, M.B., Dröge, C., Daugherty, P.J. (1991). How buyers and operations personnel evaluate service, Industrial Marketing Management, Vol. 20 pp.81-5.

[5] David, F. (2001) Strategic Management (6 ${ }^{\text {th }}$ Ed.). London :Prentice Hall.

[6] Davis, J.H., Schoorman, F.D., \& Donaldson, L. (1997).Academy of Management Review, 22: 20-47.

[7] Donald C. (2006). Synthesizing Research; A guide for Literature Reviews ( $3^{\text {rd }}$ edn) Sage: Thousand Oaks

[8] Eirma, G. (2004). Creating breakthroughs at 3M, Harvard Business Review, Vol. 77 No.5, pp.47-55.

[9] Giles, W. (1991).Making Strategy work Long RangePlanning.24(5),75-91

[10] Government of the Republic of Kenya.(1997). "Co operatives in a Liberalized Economic Environment."Session Paper No.6. Nairobi, Kenya. June 1997.

[11] Kamau,J.N. (2013), Factors influencing adoption of innovation strategy; MBA project. University of Nairobi.

[12] Kiiru, W. K. and Pederson G.d. (1996) Kenya Women Finance Trust: case study of micro Finance Scheme. Africa Region, World Bank, Washington, D.C.

[13] Kothari,C.R.(2004). Reseach Methods (2nd Ed.)New Delhi:New age International (p) Ltd.

[14] Mugenda, O.M. and Mugenda, A.G. (2003).Research Methods: Quantitative and Qualitative Research: Nairobi ; Acts Press

[15] Orodho, A. J. (2003). Essentials of Educational and Social Sciences Research Method.Masola Publishers, Nairobi.

[16] Orodho, A.J.andKombo,D.K. (2002). Research Methods. Naiobi: Kenyatta University.

[17] Porter, M.E. (1990), The Competitive Advantage of Nations, Free Press, New York, NY.

[18] Porter, M.E.(1990). The competitive Advantage of Nations. New York: Free Press. 387-390

[19] Porter, M.E. (1998). Competitive Strategy. New York: Free Press.

[20] Risk Management Guidelines for Commercial Banks \& DFIs (august 2005)

[21] Tushman, M.L., O'Reilly, C.A. (1996), Ambidextrous organization ,California Management Review, Vol. 38 pp.8-30.

[22] Ukulima (2011).Strategic Plan 2012-2016. Nairobi, Kenya.

[23] Ukulima Annual Report 2013. Nairobi, Kenya.

[24] Ukulima Annual Report 2014. Nairobi, Kenya. 


\section{International Journal of Science and Research (IJSR) \\ ISSN (Online): 2319-7064}

Index Copernicus Value (2013): 6.14 | Impact Factor (2014): 5.611

[25] Walliman, Nicholas. (2001). Your Research Project: A Step-by-Step Guide for the First-time Researcher. London: Sage Publications Inc.

[26] Wiley S. (1996) Managing Bank Capital, Bluomberg publishers, Business Park Hall 